\title{
Investigating Household Poverty Determinants of the Micro, Small and Medium Enterprise Sector in Rural Sri Lanka
}

Sarath, H.K. ${ }^{*}$, Atapattu, D. ${ }^{2}$, Sumanarathne, B.M. ${ }^{3}$

\section{Abstract}

Poverty in Sri Lanka is a predominantly rural phenomenon with more than 70 percent of the rural population. Even though rural poverty has shown a significant decrease in recent years, still many people are just above the poverty line and hence the risk of slipping back into poverty is high. Micro, small and medium enterprises (MSMEs) in the rural economy in Sri Lanka play an effective role as a means of income and employment generation resulting in a significant contribution towards reducing poverty. However, the real contribution is debated. Therefore, the main objective of this paper is to investigate the significant contribution of MSMEs towards household poverty reduction in the rural sector in Sri Lanka. This study utilized the questionnaire survey method and interview method to collect primary data. A multi-stage cluster sampling was employed to select a sample of 390 MSMEs in the Southern Province. Descriptive analysis revealed that manufacturing is the most popular business activity. The majority of entrepreneurs are sufficiently educated and experienced and finance through formal banking is the main source of capital. Key constraints demonstrated are demand problems, macroeconomic issues such as inflation, lack of finance, inadequate infrastructure and resources, and high competition. The main purpose of enterprising is the provision of basic needs for families and the majority of households generate sufficient earnings and living above the poverty line. Results of a binary logistic model showed that administrative issues; firm size, experience and business awareness, financial support, time to market, internal locus of control and entrepreneurial self-efficacy, are significant in reducing poverty in the rural sector. It is suggested to trigger MSME activities in the rural sector with necessary assistance i.e. increasing the availability of formal credit or financial access, provision of necessary infrastructure, implementing programs to improve entrepreneurial skills etc., would influence in triggering entrepreneur supply in the sector which, in turn, raises a positive impact on household wellbeing.

Keywords: Binary logistic model, Household poverty, MSMEs, Sri Lanka
${ }^{1,2,3}$ Department of Economics, University of Ruhuna, Sri Lanka

${ }^{1}$ katuku@econ.ruh.ac.lk 
INTRODUCTION

Globally, poverty is still a massive and predominantly rural phenomenon. There were around 734 million people living in extreme poverty and of which 80 percent extremely poor people live in rural areas (FAO, 2020). Poverty in Sri Lanka is also predominantly rural with more than 70 percent of the rural population (Department of Census \& Statistics, 2017). The rural sector reports a comparatively higher level of poverty amounting 4.3 per cent falling below the poverty line while the urban sector reports the lowest rates of poverty, which is 1.9. When it comes to remedial measures, globally, Micro, small and medium enterprises (MSMEs) are well acknowledged for the immense contribution towards poverty reduction through income growth, critical segment of manufacturing, employment creation or effective strategy for tackling unemployment, output diversification and also improving the trade and balance of payment (Umogbai et al., 2016) and specially, mobilization of savings and production of goods and services that satisfy the basic needs of the poor (Musara \& Gwaindepi, 2014; Muturi, 2015). In the Asian context, about 51 per cent (Thapa et al., 2013) of rural income is contributed by SMEs while it varies over 70 per cent for the Philippines and Sri Lanka and it is below 40 per cent for China, India and Nepal (Thapa et al., 2013). Hence, the dynamic role of MSMEs in developing countries through which the growth objectives of developing countries can be achieved has long been recognized (Urban \& Naidoo, 2012; Batsakis, 2014). Especially since the late 1990s, the MSME's role in poverty reduction is increasingly being recognized with its growing share (Reardon et al., 2000; Haggblade, Hazell, \& Reardon, 2010; Himanshu et al., 2013; Damayanthi \& Premaratne, 2015). Accordingly, the main objective of this paper is to investigate the significance of the effectual role of MSMEs towards household poverty reduction in the rural sector in Sri Lanka.

\section{MSMES AND THE POVERTY NEXUS}

The main theoretical work on MSMEs includes the labor surplus theory; the output-demand theory and the firm growth theory. The labor surplus theory is the main theory for the development of SMEs, which dates back to the work by Lewis (1955). This theory claims that the driving force behind the MSME's development is excess labour supply which is excluded from the formal sector due to limited absorption capacity in the public sector or large private enterprises and forced into MSMEs. According to this theory, MSMEs grew in response to the growth of unemployment and functioning as the last resort for people who could not find $\mathrm{a}$ job in the formal sector. When formal employment increases, the MSME sector is assumed to contract once more and thereby establish an anti-cycle relationship with the formal economy. The second theory that explains the expansion of the MSME 
sector is the demand-side theory and that suggests the markets for their products and services as the prerequisites for the development. Thus, the MSME sector tends to develop cyclical relationships with the economy, as a whole. However, it will also grow in competition with large corporations in the formal sector and their development will be constrained by the formal sector monopoly. The third theory is known as the firm growth theory. This theory argues that, as a result of industrialization and economic growth, MSMEs are likely to disappear and be replaced by modern large-scale industry. In all, each of the three theories has been modified into some variant. However, one of the important elements common to all the theories and variants is the proposition that the growth of MSMEs can contribute to poverty reduction.

\section{Empirical Literature on MSMEs and the Poverty Nexus}

The MSME's contribution to poverty reduction is evolving and is still being disputed. Even though the literature is replete with poverty issues and it is hard to find studies on the direct relationship between MSMEs' development and poverty alleviation especially in the developing countries. Hence, MSME poverty relation is mostly linked with the channels of growth, employment, innovation etc., and posits that MSMEs positively affect economic growth and poverty reduction. In this regard, the SME sector is believed to be able to bridge the informal and the formal sectors and provide economic opportunities for both the poor and the non-poor, leading to more equitable growth opportunities and outcomes. Hence, there is an increased interest in MSMEs as a means of accelerating economic growth and reducing poverty from the 1970s (OECD, 2009; Olawale \& Garwe, 2010). MSMEs are said to contribute to poverty reduction by increasing income, and promoting and creating employment at a faster rate (Olawale \& Garwe, 2010, Daniels and Ngwira,1994, Kowo et al., 2019, De Kok et al., 2013).

The economic literature by Beck et al. (2005) and Cravo et al. (2012), argue that MSMEs embody special advantages that proffer at least three unique contributions to the economy. Firstly, MSMEs enhance competition and entrepreneurship and hence, have external benefits on economy-wide efficiency, innovation, and aggregate productivity growth. Secondly, MSMEs are more productive than large firms but the financial market and other institutional failures prevent MSMES' development. Thirdly, MSME's expansion boosts employment more than large firms because MSMEs are more Labour-intensive (Ermias, 2017; Mohammed, 2016; the World Bank, 2002, 2004).

The majority of the studies suggest a strong positive relationship between MSME growth and economic growth and thereby, a negative relation with the incidence of poverty. In this regard, MSMEs are said to enhance 
competition and entrepreneurship and hence, have external benefits on economy-wide efficiency, innovation, and aggregate productivity growth (Cravo et al., 2012; Herman, 2012). As posited by Beck et al. (2005) and the World Bank, (2004), competition among close substitutes leads to innovation and the subsequent development of skills and MSME success. According to them, the crosscountry regressions yield a robust, positive relationship between the relative size of the MSME sector and economic growth even when controlling for many other growth determinants. Confirming this evidence, Gebremariam et al. (2004) examines the roles of small businesses in economic growth and poverty alleviation in West Virginia. In OLS and 2SLS regression analysis a positive relationship exists between small businesses and economic growth. A strong inverse relationship also exists between the incidence of poverty, small business, and economic growth. Further, evidence shows that smallscale enterprises contribute significantly to household income (Himanshu et al., 2013). It is also globally experienced that a wellorganized MSME sector is favorable to rapid industrial intensification (De Vries, 1979). Hence, it is generally agreed that the development of MSMEs can be a key ingredient in poverty reduction (Green et al., 2002; Imai et al., 2015). Consequently, the empirical results establish the linkage between small business, economic growth and the incidence of poverty.

In many developing countries, MSMEs account for the majority of firms. A large share of employment of small firms consists of one person working alone or with unpaid family members. Self-employment is a central element in these economies. In Ecuador, for example, firms with fewer than 50 employees account for 99 percent of firms and 55 percent of employment. Birch (1979) argued that small firms are particularly important in job creation. Birch (1979) reports that in the period of the 1970s firms with fewer than 100 employees generated eight out of ten new jobs in America. Beck et al. (2005) suggest that MSMEs are more productive and create more jobs than large enterprises. Supporting this idea, Olawale \& Garwe, (2010) indicate that MSMEs employ not less than 22 percent of the adult population in developing countries while Peterise (2003), claim that MSMEs both in the formal and informal sectors employ over 60 percent of the labour force in Nigeria. However, the relative importance of small producers as job creators varies significantly across countries within countries, and across stages of development over time. MSMEs with fewer than 300 workers account for 99.5 percent of the factories in Tokyo and employ 74 percent of the work force (OECD, 2017). Tunde, (2016) comparing large and small firms' ability to create employment observed that small firms are relatively better at 
creation of employment opportunities. OECD (2017), and Levy, (1993) all support this proposition.

Sutton (1997), Caves (1998) and Audretsch \& Klepper (2000), state that small enterprises have a lower survival capability and their size is negatively related to growth while small businesses serve as obstacles to economic development by attracting productive and scarce labour from their larger counterparts. On the other hand, some authors emphasize the advantages of big firms and challenge the underlying assumptions of this proMSME policy. In particular, large firms can exploit economies of scale and are easier to conduct fixed costs related to research and development with positive and productivity effects. Further, De Kok et al. (2013) and a growing body of work suggests that MSMEs do not boost the quantity and quality of employment. A wide array of evidence rejects the view that small firms are the engines of job formation (Dunne et al., 1989; De Kok et al., 2013). According to Davis, Haltiwanger and Schuh (1996), gross rates of job creation and destruction are higher in small firms, but there is no systematic relationship between net job creation and firm size (see also De Kok et al., 2013). De Wit \& De Kok (2014), show that for the European Union as a whole, smaller firms contribute more to job creation than larger firms and net job creation rates decrease with each firm size (OECD, 2017).
MSMEs are not necessarily more suitable to the labor abundance and capital shortage characteristics of developing countries. In terms of job quality, microeconomic evidence does not support the pro-SME view that small firms create better quality jobs than large firms (De Kok \& De wit, 2012). Empirical evidence suggests that firm size is not a good predictor of labour intensity, and that labour intensity varies more across industries than across firm-sized groups within industries. Many small firms are more capital - intensive than large firms in the same industry. Empirical evidence shows that large firms offer more stable employment, higher wages and more non-wage benefits than small firms in developed and developing countries, even after controlling for differences in education, experience and industry (De Kok et al., 2013). This is because of forced entry which posits that small firms are created as a last resort rather than as first choice and have therefore limited growth potential as in Liedholm \& Mead (1987) for Africa and de Soto (1989) for Latin America. Moreover, most studies of developing countries show that the smallest firms are least efficient and there is some evidence that both small and large firms are relatively inefficient compared to medium-scale firms (Little, Mazumdar \& Page, 1987). It is often argued that MSMEs are more innovative than larger firms probably due to the adoption of 'niche strategies', such as high product quality, flexibility and responsibility to 
customer needs as means of competing with large-scale businesses (Snodgrass \& Biggs 1996). However, Acs et al. (1999) found that these innovations often take time, and large firms may have more resources to adopt and implement them. Obviously, evidence from these studies rejects the view that MSMEs are the engines of job formation and growth.

In Sri Lanka, MSMEs constitute over 90 percent of total establishments and 20 percent of industrial value added (Ministry of Industry and Commerce, 2016). Further, this sector accounts for more than 75 percent of the total number of enterprises, 45 percent of the employment, and 52 percent of the GDP contribution while it provides more opportunities for women and youth participation in the economic development of the country (Ministry of Industry and Commerce, 2016). In contrast, Vijayakumar (2013) found MSMEs as an insignificant factor of growth in Sri Lanka. He has claimed on Liedholm and Mead (1987) for justification. However, methodological issues in the Vijayakumar (2013) study have taken into consideration.

It is important to note that most of the existing studies on the relationship between MSME channels and poverty have concentrated on the aggregate effects of MSMEs on poverty alleviation and especially economic growth at macro level. In this sense, the majority of researchers have attempted to establish statistical nexus between poverty rates and overall microeconomic performance based on aggregate time series data. Apart from the fact that the existing studies have neglected the individual traits of the firms, no analysis that examines MSME effect on poverty by taking a crosssection at disaggregated level with an appropriate modelling in the local setting. Hence, this study fills this gap and enriches the literature on by correcting the methodological issues and using more disaggregated data.

\section{RESEARCH METHODS}

\section{Type and design of the research}

This study focuses on the MSME sector in Sri Lanka with the expectation of prescribing that as a strategy to alleviate poverty. Applied research is one of the research types that is used to answer a specific question that has direct applications to the real world. Accordingly, this research is an applied research which is the most popular and relevant to explore the social phenomenon of poverty. Further, it involves studying the preferences, attitudes, practices, concerns, or interests of some group of people (Gay \& Airasian, 1999). Hence, this study attempts to accurately portray the characteristics of whatever entity is being studied, be it an individual or a population (Selltiz, 1976). Since the current study seeks to identify and quantify the causal factors of poverty, this is an explanatory as well as quantitative research. The best research design for the current study was nonexperimental design which uses the variables as it appears in practice. 
Working Definition

MSMEs in this study were defined according to their characteristics: ease of entry reliance on indigenous resources, mostly family ownership of resources, small scale of operation, labour -intensive, adopted technology, skills acquired outside the formal school system, and unregulated and competitive markets (ILO, 1991). The Ministry of Industry and Commerce finalized a definition for SMEs in 2016 under its "National Policy Framework for Small and Medium Enterprise (SME) Development". It is entirely based on the annual turnover and number of employees as the criteria. Accordingly, small-scale enterprises consist of number of employees between 11-50 and an annual turnover between $16 \mathrm{mn}$ and $250 \mathrm{mn}$. When the numbers of employees are between 51 and 300, and the turnover is between 251 and $750 \mathrm{mn}$, they are considered medium-scale enterprises. This study does not differentiate MSMEs under these categories and the term "industry" is used interchangeably to refer to all three types of enterprises. Further, since more than 90 percent of the MSMEs in the country and almost 98 percent of the sample are micro enterprises, this the term "micro enterprises" has also been used in some instances to represent MSMEs.

\section{Sampling Procedure}

The sample size of the current study was decided mainly considering the nature of the study objective, available time and resources; nature of the data required, capacity of the research team and economic constraints. Accordingly, this study follows the Krejcie \& Morgan (1970) table to decide the sample size. Accordingly, this number is less than 123645. The sample size is 384 since the target population is over 1000,000 enterprises. Therefore, by considering the requirements of the statistical models as well, it was decided to select a sample of 390 MSMEs from a sample frame of 123,645 non-agricultural enterprises in the Southern Province.

\section{Data Collection Method}

Demographic, Socio- economic and poverty data at different levels which are to be used in the analyses in this study are real time data. Hence, primarily the data collection process of the study is observational under which the survey research was conducted. The questionnaire method is very flexible in capturing a wide range of information in a similar manner from a large number of sampling units. Therefore, the current study uses the questionnaire as the main data collection method, while the selfadministered method was used for a part of the field survey, whilst the interview method was also employed. However, self-reporters were guided by the research team where necessary, in order to minimize the misunderstanding of questions.

\section{Empirical Model: Logistic Regression Model}

The basic aim of the secondary analysis is to examine the impact of MSME's 


\section{Original Article}

ownership and other socio-economic factors on poverty. The research question of this study is to examine the way in which poverty status is affected by demographic, socio-economic and MSME-related factors.

Depending on the research objectives, derived multidimensional asset score in terms of household assets and amenities using principal components method was used as a dichotomous dependent variable considering $40^{\text {th }}$ percentile as the threshold. The binary dependent variable takes value 1 if an SME owner is non-poor, 0 if otherwise.

Since the outcome $y_{i}$ is binary, assuming only two values coded as one and zero,

$y_{i}= \begin{cases}1 & \begin{array}{l}\text { if the ith household is non }- \\ \text { poor }\end{array} \\ 0 & \text { otherwise }\end{cases}$

Viewing $y_{i}$ as the realization of a random variable $y_{i}$ that can take the values one and zero with probabilities $\pi_{i}$ and $1-\pi_{i}$, respectively. The distribution of $y_{i}$ is a Bernoulli distribution with parameter $\pi_{i}$, and is written in compact form as,

$\operatorname{Pr}\left\{Y_{i}=y_{i}\right\}=\pi^{y_{i}}\left(1-\pi_{i}\right)^{1-y_{i}}$

If the probabilities $\pi_{i}$ depend on a vector of observed covariates $x i$, the linear probability function is:

$\pi_{i}=x_{i}^{\prime} \beta$
Where $\beta$ is a vector of regression coefficients. Transforming so that the predictor values to be within the correct range, firstly, the probability $\pi_{i}$ to the odds,

$o d d s_{i}=\frac{\pi_{i}}{1-\pi_{i}}$

This is defined as the ratio of the probability to its complement, or the ratio of favorable to unfavorable cases.

Taking logarithms of the logit or logodds,

$\operatorname{logit}\left(\pi_{i}\right)=\log \frac{\pi_{i}}{1-\pi_{i}}$

Then the logit of the underlying probability $\pi_{i}$ as a linear function of the predictors,

$\operatorname{logit}\left(\pi_{i}\right)=x_{i}^{\prime} \beta$

Where $\mathrm{x}_{\mathrm{i}}$ is a vector of covariates and $\beta$ is a vector of regression coefficients. This defines the systematic structure of the model.

Exponentiation Equation 4 for the odds of the $i^{\text {th }}$ firm to fall into the high innovative category given by

$\frac{\pi_{i}}{1-\pi_{i}}=\exp \left(x_{i}^{\prime} \beta\right)$

Solving for the probability $\pi_{i}$ in the logit model in equation 6 gives a more complicated model,

$\pi_{i}=\frac{\exp \left(x_{i}^{\prime} \beta\right)}{1+\exp \left(x_{i}^{\prime} \beta\right)}$

Accordingly, the dichotomous dependent variable of the current study takes value 1 if a household is classified 


\section{Original Article}

as non-poor or 0 otherwise, in which case, the basic model takes the form,

$y_{i}=\sum_{j=0}^{k} X_{i j} \beta_{j}+\varepsilon_{i}$

Where y denotes binary dependent variable, $\beta$ is vector of parameters and the error term $\varepsilon$ which has zero mean and logistic distribution. If $P_{i}$ is the probability that a household is classified as non-poor, it is a Bernoulli variable of which the distribution depends on the vector of predictors $X$. Then the equation 7 alternatively,

$P_{i}(X)=\frac{e^{\alpha+\beta X}}{1+e^{\alpha+\beta X}}$

The logistic function then is,

$\ln \left(\frac{P_{i}}{1-P_{i}}\right)=\propto+\sum \beta_{j} X_{i j}$

Where $\ln \left(\frac{P_{i}}{1-P_{i}}\right)$ is the natural $\log$ of the odds being considered as non-poor whereas $\beta_{j}$ is the measure of change in the logarithm of the odds ratio of the chance of the non-poor to poor.

With the logit transformation, the equation 9 is a nonlinear: $P_{i}$ is nonlinear function of all $\beta$ coefficients. Thus, given that the use of OLS is not statistically appropriate, the maximum likelihood method is most suited which yields consistent and asymptotically efficient coefficient estimates. Maximum likelihood estimates are obtained by maximizing probabilistic function with respect to the parameters.

For a given sample of firms, the probability of each household in the sample falls into defined categories given by the likelihood function of $\beta$ (Maddala, 2001),

$$
L(\beta)=\prod_{i=1}^{n}\left[P_{0}\left(x_{i}\right)^{u_{0}} P_{1}\left(x_{i}\right)^{u_{1}}\right]
$$

This is the likelihood function for $\beta$, giving for each value of $\beta$ the probability that the sampled household would choose the alternative that they actually did choose. The value of $\beta$ that yields the greatest such probability, i.e., that maximizes the likelihood function, is called the maximum likelihood estimate of $\beta$. In most specifications, under general condition this estimator is consistent and efficient (Train, 2009).

The most widely used approach is maximization of the logarithm of likelihood function. This does not impact on changing the values of parameters because the log function is monotonic and the value of $\beta$ maximizes $L(\beta)$ and also maximizes the $\log$ of $L(\beta)$. Hence the $\log$ likelihood function is

$$
\begin{aligned}
& L L(\beta)=\sum_{i=1}^{n} u_{0} P_{0}\left(x_{i}\right)+u_{1} P_{1}\left(x_{i}\right)- \\
& \ln \left(1+e^{\beta_{1} x_{i}}+e^{\beta_{2} x_{i}}\right)
\end{aligned}
$$

The maximum likelihood estimator of $\beta$ can be obtained by differentiating the $\log$ likelihood function with respect to $\beta: \partial L L(\beta) / \partial \beta_{j k}$.

The Binomial logit model generated as in eation10, expresses a ratio of log of odds is a function of vectors of $\beta$ and a vector of independent variables, $x$. Expanding this expression by including variables used in the study the operational models were specified. 


\section{Original Article}

ISSN: 2279-3933

\section{Model Assessment}

The statistical validity and sufficiency were assessed in terms of sample size, evaluation of overall measures, examinations of individual components of the summary statistics, and examination of other measures of the difference or distance between the actual and estimated probabilities (Hosmer \& Lemeshow, 2000). Practically, several measures and criteria have been developed for a specified logistic model i.e., likelihood ratio test, pseudo $\mathrm{R}^{2,}$ Wald test (Hausman \& McFadden, 1984).

\section{RESULTS AND FINDINGS}

\section{Sample Characteristics and Descriptive Statistics}

\section{Profile of Entrepreneurs}

In terms of demographic characteristics, there can be a gender balance in the sample recording the values 50.9, and 49.1 for females and males respectively. Generally, female representation in the MSMEs is somewhat high in the rural sector. As it is observed from Table 1, more than one-third of entrepreneurs are in the 18 - 40 age groups while a higher proportion, 24.3 per cent, are between 40 to 50 years. This shows that the majority of them belong to the country's working population. Interestingly, a considerable percent of entrepreneurs are in the " 50 years and above" age group.
Table 1: Age and education level of SME

\begin{tabular}{|c|c|c|c|}
\hline $\begin{array}{l}\text { Age } \\
\text { (Years) }\end{array}$ & $\begin{array}{c}\text { Entrepr } \\
\text { eneurs }\end{array}$ & $\begin{array}{c}\text { Educatio } \\
\mathrm{n} \text { level }\end{array}$ & $\begin{array}{l}\text { Entrepr } \\
\text { eneurs }\end{array}$ \\
\hline 18 - & 1.90 & $\begin{array}{l}\text { Primary } \\
\text { Junior } \\
\text { secondar }\end{array}$ & 3.80 \\
\hline $18-30$ & 7.50 & $\mathrm{y}$ & 12.70 \\
\hline $30-40$ & 27.60 & $\mathrm{O} / \mathrm{L}$ & 48.40 \\
\hline $40-50$ & 24.30 & $\mathrm{~A} / \mathrm{L}$ & 31.80 \\
\hline $50+$ & 38.20 & Graduate & 3.20 \\
\hline
\end{tabular}

Source: Author's calculations based on sample survey

The level of education reported in Table 1 shows that there is no illiteracy and only 3.8 per cent of the entrepreneurs were educated up to primary level, indicating a higher level of educational attainment in the country. Although more educated entrepreneurs like graduates were only a very few percent, more than three-fourths of the sample have at least $\mathrm{O} / \mathrm{L}$ qualification. The $\mathrm{A} / \mathrm{L}$ pass percentage is very considerable (31.8) while most of the households have at least one A/Leducated member although the educational level of parents is very low.

Table 2: Experience in the enterprise activity

\begin{tabular}{lclc}
\hline $\begin{array}{l}\text { Experie } \\
\text { nce in } \\
\text { years }\end{array}$ & $\begin{array}{c}\text { entre } \\
\text { pre } \\
\text { neurs }\end{array}$ & $\begin{array}{l}\text { Employ } \\
\text { ment }\end{array}$ & $\begin{array}{l}\text { Category } \\
\text { entrepren } \\
\text { eurs }\end{array}$ \\
\hline Below 2 & 18.2 & $\begin{array}{l}\text { Salaried } \\
\text { Job }\end{array}$ & 21.1 \\
$2-5$ & 19.4 & $\begin{array}{l}\text { Own } \\
\text { business }\end{array}$ & 78.9 \\
$6-10$ & 22.0 & & \\
\hline
\end{tabular}




\section{Original Article}

ISSN: 2279-3933

\begin{tabular}{lc}
$11-15$ & 11.5 \\
$16-20$ & 12.9 \\
$21-25$ & 5.8 \\
$\begin{array}{l}\text { Above } \\
25\end{array}$ & 10.6 \\
\hline
\end{tabular}

Source: Author's calculations based on sample survey

Table 2 presents the experience and previous employment category of the entrepreneurs. It was evident that most of the enterprise operators are experienced enough in the same business or in the field. Approximately 80 percent of them have above two years of experience while most of them have more than 10 years of experience. Ten-point six (10.6) percent of them are very well experienced having more than 25 working years. Only 21 percent of the samples were salaried employees before starting the business while the majority of the surveyed were entrepreneurs previously.

\section{Profile of Enterprises}

The repartition of MSME owner enterprises by activity in sampled rural sectors is given in Table 3 . It is quite interesting to see that manufacturing is the most popular revenue source or enterprise activity in the rural sector, which records almost half of the enterprises. Share of food processing was recorded as the second major economic activity recording 15 percent whilst dressmaking and salon are significant proportions as well. Commerce activities constitute only 21 percent of other sectors, however much less significant in numbers or quantity; nevertheless, constitute an important part of the informal sector.

Table 3: Main enterprise activities

\begin{tabular}{|c|c|c|c|}
\hline $\begin{array}{l}\text { Main } \\
\text { category }\end{array}$ & & $\begin{array}{l}\text { Enterprise } \\
\text { activity }\end{array}$ & $\begin{array}{l}\% \text { of } \\
\text { enterprises }\end{array}$ \\
\hline \multirow[t]{3}{*}{ Commerce } & 20.9 & & \\
\hline & & Groceries & 2.0 \\
\hline & & $\begin{array}{l}\text { Food Processing } \\
\text { Communic } \\
\text { ations/ } \\
\text { stationary }\end{array}$ & 14.9 \\
\hline \multirow[t]{4}{*}{ Services } & 31.8 & & \\
\hline & & Service / repair & 4.1 \\
\hline & & Dress making & 12.2 \\
\hline & & $\begin{array}{l}\text { Tinker / welding } \\
\text { Saloon / beauty } \\
\text { cultural }\end{array}$ & 10.8 \\
\hline $\begin{array}{l}\text { Manufac } \\
\text { tures }\end{array}$ & 47.3 & Small industries & 47.3 \\
\hline
\end{tabular}

Source: Author's calculations based on sample survey

Table 4: Percentage (\%) of enterprises by the number of workers employed ${ }^{\text {a }}$

\begin{tabular}{cccc}
$\begin{array}{c}\text { Number } \\
\text { of } \\
\text { workers }\end{array}$ & $\begin{array}{c}\text { Total } \\
\text { workers }\end{array}$ & $\begin{array}{c}\text { Family } \\
\text { workers }\end{array}$ & $\begin{array}{c}\text { Other } \\
\text { workers }\end{array}$ \\
\hline 0 & 55.6 & 65.1 & 34.6 \\
1 & 22.2 & 21.3 & 76.8 \\
2 & 7.8 & 17.5 & 77.1 \\
3 & 4.4 & 12.5 & 87.4 \\
4 & 3.3 & 11.3 & 89.6 \\
5 & 1.1 & 1.3 & 97.8 \\
6 & 0.6 & 1.2 & 97.8 \\
8 & 0.6 & 1.3 & 98.7 \\
$10+$ & 2.4 & 6.9 & 98.6 \\
\hline
\end{tabular}

Source: Author's calculations based on sample survey

a excluding owner 
Table 4 shows that more than half of the entrepreneurs are own-account workers employing no worker other than the owner. The majority of them (65\%) do survival businesses while 21 percent of them have only one worker. Percentage of firms employing more than 5 workers is almost 1 percent. Further, it was revealed that the establishments with over 10 persons engaged were 2.4 percent while persons engaged over 20 were only 0.6 percent for the sample.

It was obvious that the majority of employees in one-worker firms are family members. Only a small proportion of enterprises have paid workers although the mean age of an enterprise was 11.45 years (see Table 5). However, it is very important that the microenterprises in the rural sector have contributed to the national economy providing at least one additional employment. It is obvious that the majority of them have no expansion or development of the activities up to any level but have just survived. Therefore, the concept of firm graduation is still lacking in the sector. Reasons behind this behavior might be attributed mainly due to their objectives of starting the activity and other functioning obstacles as well. However, it should be noted that almost one fifth of the enterprises are newly established and less than two years in operation while another 20 percent is less than 5 years in age as shown in Table 5. Evaluation of vision and improving capacity of these young entrepreneurs will mirror the future of their enterprises.

Table 5: Percentage of enterprises according to age of firm

\begin{tabular}{llll}
\hline Age of firm & $\%$ & $\begin{array}{l}\text { Descriptive } \\
\text { of firm }\end{array}$ & statistics \\
\hline $\begin{array}{l}\text { Less than } 2 \\
\text { years }\end{array}$ & 18.1 & Mean & 11.45 \\
3 - 5 years & 21.3 & Median & 8.00 \\
6 - 10 years & 22.5 & Mode & 1.00 \\
11 - 15 years & 12.5 & Maximum & 60.00 \\
$16-20$ years & 13.1 & & \\
$20-25$ years & 4.0 & & \\
above 25 & 7.5 & & \\
years & & \\
\hline
\end{tabular}

Source: Author's calculations based on sample survey

As it has been found, the most preferred borrowing method of the majority of rural informal sector micro entrepreneurs is formal borrowing. As pointed out by many researchers micro and small entrepreneurs in developing countries have hardly access to formal financial institutions due to various types of borrowing constraints. However, quite differently, 40 percent of micro and small enterprises in the rural sector have been initiated with bank loans or private savings where only a negligible percentage (2.6) has obtained private loans.

\section{Key issues faced by MSMEs}

Some of the key issues demonstrated by surveyed MSMEs are economic condition of the country which related to demand problems, lack of finance, inadequate infrastructure facilities, and competition as shown in the Table 6. 
Table 6: Main issues faced by MSMEs (\%)

\begin{tabular}{|c|c|c|c|c|}
\hline \multirow[t]{2}{*}{ Problems } & \multicolumn{4}{|c|}{ Rank (\%) } \\
\hline & 1 & 2 & 3 & $\begin{array}{l}\text { Cite } \\
\mathrm{d} \text { as } \\
\text { an } \\
\text { issue }\end{array}$ \\
\hline $\begin{array}{l}\text { Resources and } \\
\text { materials }\end{array}$ & $\begin{array}{c}46 . \\
0\end{array}$ & 12.0 & $\begin{array}{c}10 . \\
0\end{array}$ & 19.3 \\
\hline $\begin{array}{l}\text { insufficient } \\
\text { Infrastructure } \\
\& \\
\text { administratio } \\
n\end{array}$ & $\begin{array}{c}39 . \\
0\end{array}$ & 31.0 & $\begin{array}{c}15 . \\
0\end{array}$ & 14.5 \\
\hline $\begin{array}{l}\text { Competition } \\
\text { among } \\
\text { MSMEs }\end{array}$ & $\begin{array}{c}35 . \\
0\end{array}$ & 39.0 & $\begin{array}{c}14 . \\
0\end{array}$ & 12.9 \\
\hline $\begin{array}{l}\text { Economy } \\
\text { wide } \\
\text { conditions }\end{array}$ & $\begin{array}{c}32 . \\
0\end{array}$ & 52.0 & $\begin{array}{c}28 . \\
0\end{array}$ & 11.6 \\
\hline $\begin{array}{l}\text { Product } \\
\text { demand }\end{array}$ & $\begin{array}{c}30 . \\
0\end{array}$ & 15.0 & $\begin{array}{c}11 . \\
0\end{array}$ & 11.4 \\
\hline Capital loans & $\begin{array}{c}28 . \\
0\end{array}$ & 7.0 & $\begin{array}{c}11 . \\
0\end{array}$ & 11.3 \\
\hline $\begin{array}{l}\text { Labor supply } \\
\text { and income }\end{array}$ & $\begin{array}{c}18 . \\
0\end{array}$ & 27.0 & $\begin{array}{c}16 . \\
0\end{array}$ & 11.3 \\
\hline
\end{tabular}

Source: Author's calculations based on sample survey

Limited access to capital and acquisition of required resources are to be the primary obstacles of enterprise income in the sector (64\%). Most entrepreneurs still do not have access to the capital they need to grow their enterprises. Moreover, obtaining raw materials is also a significant issue. This implied the problem of utilizing available resources efficiently. Among the manufacturing entrepreneurs interviewed, two third of them cited lack of capital as the most significant obstacle to their growth and success (evidence from focus group interviews). However, in the very general scenario, this cannot be seen as the prominent for several reasons. Firstly, it was shown that many entrepreneurs are not sufficiently aware of the capital and credit options available to them. A considerable percentage of entrepreneurs were least aware of the credit or savings programs. Secondly, they fundamentally believe that they are not accepted by the banking sector due to collateral and other paper works and therefore purposely avoided searching credit related matters.

Thirdly, competition and the demand related issues are the main obstacles. If there is less money circulating in the economy, which obviously impacts on demand for products and services and well as their supply. With the limited or somewhat fixed market, many microenterprises have to struggle to sell products to people that can barely afford them. Hence the economy wide condition has been seen as a major problem by a considerable percentage of enterprises. However, the people who have sub contracts with large firms are less likely to face demand problems. Further, this implies that MSMEs lack having proper market chains and also lack of adopting proper marketing strategies. Further, lack of skills to produce the goods as per market demand seems a major problem.

Further, almost 40 per cent have reported administrative and infrastructure related issues as their 
prominent constraint while almost 14.5 percent have cited it as a problem. The role of infrastructures is key to making MSMEs function optimally. Inadequate supply of infrastructure has long been an issue in the rural MSME sector (Shaw, 2004).

\section{Firm dynamics and poverty}

Type of the clients guarantees the stability of the revenue flow for an enterprise. As it was found, the public is the customers for the majority (33\%) while; there are a considerable percentage of enterprises which have contracts with large firms (5\%) and with small firms (15\%).

Why they have chosen their own business instead of joining a salaried job was a primary question to examine "whether these people are excluded from the modern sector". If they are excluded, as there is no alternative, they have to do something to survive though it is not intended. This can be examined indirectly by considering enterprise returns with minimum wages. For about 41 percent households, enterprise earnings are the sole source of income. This does not necessarily mean that all of them are operated on a full-time basis. However, as shown in Table 8 the majority worked more than full time basis that is above 48 hours, which is considered as the basis to calculate minimum salary, per week. On average especially entrepreneurs operate 50 hours per week and more than 65 percent of entrepreneurs work more than 48 hours per week. Mode number recorded was 56 hours per week with a median of 54 hours.

Table 7: Percentage of entrepreneurs by average hours worked

\begin{tabular}{lc}
\hline Hours per week & $\%$ \\
\hline 48 below & 32.7 \\
$48-60$ & 40.7 \\
$61-70$ & 10.2 \\
$71-84$ & 8.2 \\
85 above & 6.1 \\
\hline
\end{tabular}

Source: Author's calculations based on sample survey

Due to the variation in the number of hours worked per week or per month, direct comparison of monthly earnings with the formal sector is not possible. Therefore, some adjustment has to be done to make the figures comparable. An hourly return for micro entrepreneurs was calculated taking total hours worked per month. Hourly earnings were taken dividing total earnings by total worked hours on a full-time basis. Minimum wage for any sector in Sri Lanka has been decided on the basis of 48 hours per week. Therefore, the minimum wage for the year 2016 for any sector, Rs. 10,000.00, divided by 192 (monthly basis $48 \times 4$ $=192$ ) to construct hourly wage line in order to conduct a full-time basis comparison. 


\section{Original Article}

Figure1: Distribution of entrepreneurs by earning level

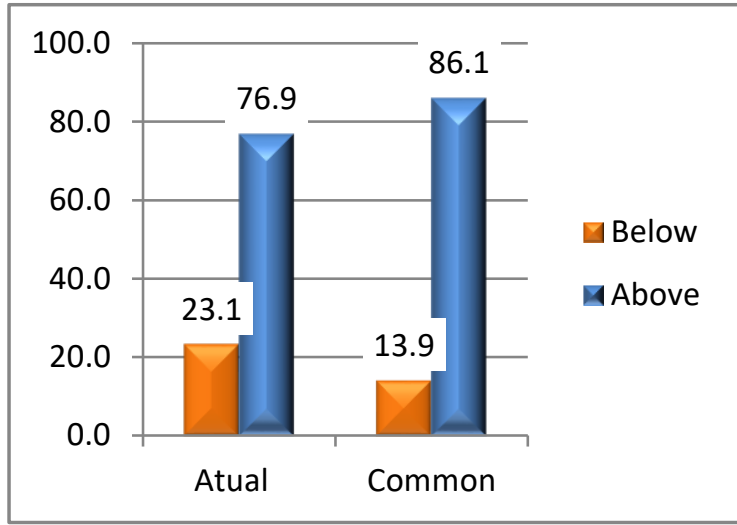

Source: Author's calculations based on sample survey

Table 8: Comparison of enterprise earnings to minimum wage

\begin{tabular}{ll}
\hline Status of earning & $\begin{array}{l}\text { Minimum wage any } \\
\text { sector } \\
\% \text { of entrepreneurs }\end{array}$ \\
\hline
\end{tabular}

\begin{tabular}{ll}
\hline $\begin{array}{l}\text { Below minimum } \\
\text { wage }\end{array}$ & 28.5 \\
Equal to minimum & \\
wage & 35.3 \\
2 times above the & 24.2 \\
minimum wage & 6.8 \\
3 times above & 1.4 \\
4 times above & 3.8 \\
More than 5 times
\end{tabular}

Source: Author's calculations based on sample survey

Figure 1 shows that 23 percent of entrepreneurs are below the minimum wage of any sector confirming a significant exclusion when the actual working hours are considered. This percentage is reduced to 13 percent if accepted work norm (48 hours per week) is considered. Since education plays a vital role in getting a good job in the country in general, low education levels of this group have naturally pushed them out from reaching the government sector. The driving force for this group might be the unavailability of opportunities.

With reference to Table 8 , however there can be seen a group of entrepreneurs who are earning even three to six times the minimum wage. This percentage is about 12 percent while around 35 percent of them earns an equal amount to minimum. This group should be neutral in running the business or shifting into a job when a chance comes. Almost 35 percent earns more than double the minimum. It shows that the minority who are above the wage line signifies the importance of enterprise activities in reducing poverty in the rural sector.

The majority of the households (65\%) survive solely from enterprise earnings. Therefore, the poverty level of the household has crucial implications on the firm growth vice versa. The level of poverty has been identified as one of the major factors that affect throughout. Generally, poverty is the main reason behind taking risk which is also a very important factor behind the activity selection process. If they are not wealthy enough to meet basic needs their efforts towards new productions, experiments, advertising, or searching for new markets will be very limited. Thus, the sufficiency of enterprise earnings is important. 


\section{Original Article}

To analyze the sufficiency, the earnings of entrepreneurs that provide all of household income can be compared to the absolute poverty line, "the minimum level of food and non-food expenditure deemed necessary to satisfy a person's food requirement" (DCS, 2004) in the country. Poverty line figures for Matara, Galle and Hambantota districts in December, 2016 were Rs. 3,992, 3,967 and 3,804 respectively. Accordingly, the average poverty line for the province was calculated as 3921. Repartition of MSMEs according to their poverty status is shown in Table 9.

Table 9: Comparison of enterprise income and monetary poverty

\begin{tabular}{|c|c|c|c|}
\hline Status & $\begin{array}{c}\text { Percentage } \\
\text { of } \\
\text { entreprene } \\
\text { urs }\end{array}$ & $\begin{array}{l}\text { Status } \\
\text { with } \\
\text { poverty } \\
\text { line }\end{array}$ & $\begin{array}{c}\text { Percentage } \\
\text { of } \\
\text { entreprene } \\
\text { urs }\end{array}$ \\
\hline $\begin{array}{l}\text { Below } \\
\text { poverty } \\
\text { line }\end{array}$ & 17.7 & $\begin{array}{l}\text { Equal or } \\
\text { below }\end{array}$ & 32.5 \\
\hline \multirow{4}{*}{$\begin{array}{l}\text { Above } \\
\text { poverty } \\
\text { line }\end{array}$} & 82.3 & $\begin{array}{c}2 \text { times } \\
\text { above }\end{array}$ & 36.0 \\
\hline & & $\begin{array}{c}3 \text { times } \\
\text { above }\end{array}$ & 12.8 \\
\hline & & $\begin{array}{l}4 \text { times } \\
\text { above }\end{array}$ & 8.9 \\
\hline & & $\begin{array}{l}5 \text { or } \\
\text { more }\end{array}$ & 9.8 \\
\hline
\end{tabular}

Source: Author's calculations based on sample survey
It shows that more than 80 percent of households are above while 36 percent of them earn at least two times the line. Considerable proportion of households make even three times the poverty line. These results indicate that the majority of households generate sufficient earnings to meet the absolute poverty line in the sector. However, it should be stressed that the meeting of the absolute poverty line does not imply that they have the ability of moving into higher order needs which give an entrepreneur more freedom improving related decisions. Although the majority of them are above the absolute poverty line they spend more than 80 percent of the earnings for their basic food, shelter and educational ends as discussed above. It is obvious that they are not the poor according to income poverty measures and their businesses have helped them to meet basic needs. However, the level of poverty is influential to expand their economic activities. 
Table 10: Entrepreneurs by allocation of net enterprise income (\%)

\begin{tabular}{lccccc}
\hline \multirow{2}{*}{ Purpose } & \multicolumn{5}{c}{ Allocation of net income \% } \\
\cline { 2 - 6 } & below 10 & 10 to 25 & 26 to 50 & 51 to 75 & $\begin{array}{c}76 \\
\text { above }\end{array}$ \\
\hline Food & 30.4 & 9.1 & 48.6 & 10.1 & 1.7 \\
Non-food & 68.2 & 14.9 & 2.4 & 0 & 0 \\
Education & 82.8 & 14.9 & 2.4 & 0 & 0 \\
Housing & 93.9 & 5.1 & 1.0 & 0 & 0 \\
Saving & 81.4 & 10.8 & 7.1 & 0.7 & 0 \\
Bus. improve & 75.7 & 13.9 & 8.1 & 1.7 & 0 \\
Entertainments & 98.6 & 1 & 0.3 & 0 & 0 \\
\hline
\end{tabular}

Source: Author's calculations based on sample survey

It was evident that more than 70 percent of them do business activities in order to provide food, shelter and education to their families. Education is also at the least end while no or a tiny allocation has been made for entertainment. This described how entrepreneurs are dependent on the enterprise income in fulfilling their basic needs and accordingly the importance of the enterprise in getting out of poverty (Refer table 10).

\section{RESULTS AND DISCUSSION}

Binary logistic model for poverty determinants in rural MSME sector

This section presents the results and discussion of estimated binary logistic models in order to examine factors that determine the probability of being poor and thereby analyze how enterprise related factors impact on poverty status of MSME owners. The dependent variable is categorical describing different poverty levels: non-poor and poor. The coefficients presented in

Table.11 describe the effect of the corresponding variable on the odds (ratio of two probabilities) of the level of interested relative to the base level, in this study the base is "poor" or respondents who fall below the trimmed mean of the asset index. A coefficient above unity implies that the corresponding explanatory variable increases the odds of belonging to the level of interested relative to the group "poor." Conversely, a coefficient below unity implies that the variable decreases the odds.

Table 11: Determinants of poverty: Binary logistic estimates

\begin{tabular}{llll}
\hline Variable & Coefficient & SE & $\mathrm{OR}^{\mathrm{a}}$ \\
\hline Constant & -14.392 & 6.520 & \\
Age & -0.01 & 0.031 & 0.369 \\
Gender & -0.488 & 0.804 & 0.217 \\
Marital & 0.568 & 1.330 & 0.182 \\
Edu_yrs & $1.31^{* *}$ & 0.511 & 3.694 \\
Spouse_Edu_yrs & $1.32^{* *}$ & 0.442 & 3.103 \\
Hours_worked & 0.234 & 0.319 & 1.263 \\
Admin_prob & & 0.01 & \\
(Less) & $0.11^{*}$ & & 1.01 \\
Firm_size & $0.18^{* *}$ & 0.05 & 1.19 \\
\hline
\end{tabular}




\begin{tabular}{|c|c|c|c|}
\hline Experience & $0.07^{*}$ & 0.01 & 1.07 \\
\hline Aware & $0.15^{* *}$ & 0.07 & 1.05 \\
\hline Pev_job & 0.22 & 0.10 & 1.25 \\
\hline Time_market & $0.014^{*}$ & 0.008 & 1.014 \\
\hline Formal_credit & $1.162^{* *}$ & 0.461 & 3.196 \\
\hline LOC_in & $1.37^{* *}$ & 0.594 & 5.671 \\
\hline LOC_ex & -0.891 & 0.478 & 0.410 \\
\hline ESE & $0.823^{* *}$ & 0.361 & 2.277 \\
\hline
\end{tabular}

As pointed out in the Table. 11 demographic factors included in the model have no prediction power on the probability of being poor in this sector. Age, gender, and marital status are not significant at any level of significance. Education is positively significant at 5 percent level of significance. $\chi^{2}(1)=$ $1.31, \mathrm{p}<.05$ for the owner and $\chi^{2}(1)=$ $1.32, \mathrm{p}<.05$ for spouse respectively. Except for some psychic factors, education is the most prominent which increasingly effects the odds of being non-poor. A year change in education will increase odds for the sector by more than 6.5 times. This further confirms the reference group is much more likely to be in this group compared to those who have a comparatively higher level of education. Secondary level of education has much more preference in the rural enterprises because the dropouts of $\mathrm{O} / \mathrm{L}$ and $\mathrm{A} / \mathrm{L}$ have fewer opportunities in the formal sector unless they are qualified with any other professional experience. They tend to remain in the micro enterprise sector. Overall, this suggests that education is a triggering matter in running the business effectively and entrepreneur supply in the sector in contrast to some of the studies in the literature that indicates education of the owner has apparently no impact (Davidsson, 2006).

\section{Enterprise related factors}

Respondent's perception on administrative issues; firm size, experience and business awareness are positive and significant at conventional levels recording the beta values as 0.18 , 0 , 07, 0.15, respectively. Generally, MSMEs who face administrative difficulties are less likely to improve their business activities. Thus, simple and friendly administration procedures seem to be helping in earning more money, more wealth and more wellbeing in the sector. Obviously, a comparatively large firm owner earns sufficiently and therefore probability of being in non-poor group is usual. Thus, it was clearly found the need of graduating micro firms into small, medium to get them out of poverty. Strong significance of business awareness and also experience implies the use of knowledge in raising earnings.

Insignificance of the impact of previous employment on the odds of being at any level clearly suggests the nature of the informal sector employment pattern which mainly consists of low paid low skilled workers. They might not have entrepreneurial skills acquired through the jobs, accumulated capital to utilize as enterprise capital. They are in need of supportive income 
to satisfy lower order physiological and safety needs and hence entered into the microenterprise sector. Their effort is to make sufficient money rather than a growing company (Roy \& Wheeler, 2006).

Financial factors for the current model consider the availability of formal and semiformal financial support. Regarding how the lack of financial support influences, the important result is that it is one of the more prominent factors on the risk of falling into poverty. This variable is considerably significant, $\chi^{2}(1)=1.162$, $\mathrm{p}<.05$ having positive relation with wellbeing status. Strong significance of this variable proves the fact that availability of financial support plays a crucial role in an individual's attitude toward entrepreneurship. Increase in the unit of the variable predicts an increase of odds by more than six times. However, this variable is the most crucial one when it comes to the odds ratio which gives the policy direction.

Availability of necessary infrastructure seems to encourage an active involvement in entrepreneurial activity in the sector more significantly. "Variable time to market" included in the model to represent infrastructure facilities for the rural enterprise sector. As shown in the Table. 11, regression coefficient of "Time market" is positively significant at 5 percent level with odds ratio of 1.014. Basic facilities are a crucial binding factor for the micro enterprises especially in rural settings which effects on collecting raw materials as well as providing the production to the market on time. Failure or delays of these activities will affect enterprise income and thereby on poverty status of the entrepreneurs. Therefore, improvement of infrastructure in the rural sector plays an important role in entrepreneur upliftment.

Two psychological factors seem more important in predicting asset position and thereby poverty of MSME owners significantly. Entrepreneurial Self Efficacy (ESE) is strongly positively significant, $\chi^{2}(1)=0.823,5$ percent level of significance. A unit change in the value will lead to increased odds by more than two times showing the fact that the importance of entrepreneurial skill on the enterprise income in the sector. Internal locus of control as measured by the Rotter Scale is very significant recording $\chi 2(1)=1.37$, $\mathrm{P}<0.05$. The favorable change in this factor will lead to increased odds much strangely. Hence, perceived selfefficacy seems to contribute significantly to reducing poverty in the sector (De Mel et al., 2008; Fairoz et al., 2010; Sumanasena, 2005).

\section{CONCLUSIONS}

Given the importance of enterprise sector as the backbone of the economy, the main objective of this paper is to investigate the MSMEs' significance towards household poverty reduction in rural Sri Lanka. Comprehensively conducted descriptive analysis 
revealed that manufacturing is the most popular business activity among the sampled MSMEs while the majority of the entrepreneurs are sufficiently educated and experienced.

Poverty covariates of MSME owners were examined utilizing a binary logistic model. Other than demographic variables, the set of explanatory variables used includes education, availability of formal credit, previous employment infrastructure availability, respondent's perception on administrative issues; hours worked a week, firm size, experience and business awareness and two psychological measures: ESE, LOC. Results of binary logistic models found that Age, gender, marital status or previous employment have no predicting power over the probability of being non-poor while favorable change in all the other factors plays a crucial role predicting poverty in the sector. Education is positively significant and it is the most prominent factor which increasingly effects the odds of being non-poor. Enterprise related factors: respondent's perception on administrative issues; firm size, experience and business awareness, availability of financial support, Time to market, two psychological factors, internal LOC and Entrepreneurial self-efficacy are positive and significant.

These results indicate that the majority of households generate sufficient earnings to meet the absolute poverty line in the sector. However, it should be stressed that the meeting of the absolute poverty line does not imply that they have the ability of moving into higher order needs which give an entrepreneur more freedom improving related decisions. The majority of them are above the absolute poverty line and met their basic food, shelter and educational ends utilizing the enterprise income. It was obvious that their businesses have helped them to meet basic needs signifying the importance of enterprise activities in reducing poverty in the rural sector.

Thus, it is suggested to trigger micro and small business activities in the sector with necessary assistances, i.e., increasing the availability of formal credit or the financial access, provision of necessary infrastructure, programs to improve entrepreneurial skills etc., would influential in triggering entrepreneur supply in the sector which intern raise positive impact on household wellbeing.

With regards to administrative issues, research findings suggest that when entrepreneurs have become a business owner, administrative complexity and postponement play a crucial role for most contributing entrepreneurs. This provides a deeper insight to policymakers about the most "effective" targets for policy initiatives in the field of administrative simplification. Hence, efforts can be taken to minimize disruptive factors such as administrative problems (licenses, approvals, infrastructure provision 
etc.) in order to increase enterprise income and thereby reduce poverty.

Moreover, the establishment of coordination and assisting intermediary institutions or organizations will be an effective solution for bridging the gap of knowledge on resource search and administrative barriers. Such establishments may support MSME entrepreneurs for matters related to market research, practical research and advocacy relating to policies, laws, regulations, and administrative barriers. This will help to resolve the issues increasing entrepreneur's household income.

Furthermore, it is shown that the lowest diversity resulting from the selection of irrational activities through other copying has created the advantages of supply of goods. Hence, low demand and high competition have made them prolonged, unstable income, and unmistakable businesses most faced by the majority of micro enterprises in this sector. Connecting micro entrepreneurs to the market through larger commercial firms helps address this problem. In this case, using contractual arrangements to link companies with larger commercial firms is more effective in building sustainable businesses than working through governments or district councils. Such an activity diversifies enterprise income which will result in reducing household vulnerability.

\section{ACKNOWLEDGEMENT}

It is greatly acknowledged the funds given by NCAS in completing this project successfully.

\section{References}

Acs, Z., Morck, R., \& Young, B. (1999). Productivity Growth and Size Distribution. In Z. Acs, B. Carlsson, \& C. Karlsson, Entrepreneurship, Small and Medium-Sized Enterprises, and the Macroeconomy. Cambridge: : University Press.

Audretsch, D. B., \& Kleper, S. (2000). Innovation, Evolution of Industry and Economic Growth. Cheltenham, U.K. and Northampton: Mass.

Batsakis, K. G. (2014). Impediments on the way to entrepreneurship. Some new evidence from the EU's post-socialist world. Journal of Small Business and Enterprise Development, 385-402.

Beck, T., Demirguc-Kunt, A., Laeven, L., \& Levine, R. (2005). Finance,Firm Size and Growth. Washington, DC: The World Bank.

Birch, D. L. (1979). The Job Generation Process:Final Report to Economic Development Administration MIT Program on Neighborhood and Regional Change. Cambridge: MIT Program on Neighborhood and Regional Change.

Caves, R. E. (1998). Industrial Organization and New Findings on theTurnover and Mobility of Firm. Journal of Economic Literature, 36(2), 1947-1982.

Cravo, T. A., Gourlay, A., \& Becker, B. (2012). SMEs and Regional Economic Growth in Brazil. Small Business Economics, 38(2), 217-230.

Damayanthi, B. W., \& Premaratne, G. (2015). Entrepreneurial Engagement Choice and Credit Constraints: Empirical Analysis of Urban Informal Microentrepreneurship in Sri Lanka. Asian Social Science, 11(26), 30-42.

Daniels, L., \& Ngwira, A. (1994). Results of a Nation-Wide Assessment on Micro, Small 
and Medium Enterprises in Malawi. New York: PACT Publication.

Davidson, P. (2006). Nascent Entrepreneurship: Empirical Studies and Developments. Foundations and Trends in Entrepreneurship Research, 2(1), 1-76.

Davis, S. J., Haltiwanger, J., \& Schuh, S. (1996). Small Business and Job Creation: Dissecting the Myth and Reassessing the Facts. Small Business Economics, 8(4), 297315.

DCS. (2017). Poverty Indicators Household Income and Expenditure Survey - 2016. Colombo: Department of Census and Statistics.

De Kok, J., \& De Wit, G. (2012). Determining the Contribution of Size Classes to Employment Growth. An Application of the Method of Dynamic Classification for the European Union. Zoetermeer: Panteia.

de Kok, J., Deijl, C., \& Van EssenIs, C. V. (2013). Is Small Still Beautiful? Literature Review of Recent Empirical Evidence on the Contribution of SMEs to Employment Creation. Eschborn: Deutsche Gesellschaft fur Internationale Zusammenarbeit(GIZ).

De Mel, S., McKenzie, D., \& Woodruff, C. (2012). Returns to Capital in Microenterprises: Evidence from a Field Experiment. The Quarterly Journal of Economics, 123(4), 1329-1372.

de Soto, H. (1989). The Other Path. New York: Harper and Row.

DE VRIES, B. (1979). Industrialization and Employment: The Role of Small- and Medium-Sized Manufacturing Firms (English). Washington: World Bank Group.

de Wit, G., \& de Kok, J. (2014). Do Small Businesses Create More Jobs? New Evidence for Europe. Small Business Economics, 42(2), 283-295.

Department of Census and Statistics(DCS). (2004). Announcement of the Official Poverty Line. Colombo: Department of Census and Statistics.

Dunne, T., Roberts, M. J., \& Samuelson, L. (1989). The Growth and Failure of U. S.
Manufacturing Plants. The Quarterly Journal of Economics, 104(4), 671-698.

Ermias, E., Mekdim, D., Ibrahim, W. S., \& Feiruz, Y. (2017). The Role of Micro and Small Enterprises in Reducing Unemployment and Poverty in Ethiopia. Addis Ababa: Partnership for Economic Policy.

Fairoz, F. M., Hirobumi, T., \& Tanaka, Y. (2010). Entrepreneurial Orientation and Business Performance of Small and Medium Scale Enterprises of Hambantota District Sri Lanka. Asian Social Science, 6(3), 34-42.

FAO. (2020). COVID-19 and Rural Poverty: Supporting and Protecting theRural Poor in times of Pandemic. Rome: Food and Agriculture Organization of the United Nations.

Gay, L. R., \& Airasian, P. W. (1999). Educational Research: Competencies for Analysis and Applications (6th ed.). New Jersey: Pearson College Division.

Gebremariam, G. H., Gebremedhin, T. G., \& Randall, W. (2004). The Role of Small Business in Economic Growth and Poverty Alleviation in West Virginia: An Empirical Analysis. West Virginia: American Agricultural Economic Association.

Green, C. J., Kimuyu, P., R, M., \& Murinde, V. (2002). How do Small Firms in Developing Countries Raise Capital? Evidence from a Large-Scale Survey of Kenyan Micro and Small Scale Enterprises (MSES). Manchester: Institute for Development Policy and Management.

Haggblade, S., Hazell, P., \& Reardon, T. (2010). The Rural Nonfarm Economy: Prospects for Growth and Poverty Reduction. World Development, 38(10), 1429-1441.

Hausman, J., \& McFadden, D. (1984). Specification Tests for the Multinomial Logit Model. Econometrica, 52(5), 12191240.

Herman, E. (2012). SMEs and Their Effect on the Romanian Employment. Procedia Economics and Finance, 3, 290-297.

Himanshu, L. P., Murgai, R., \& Stern, N. (2013). Nonfarm Diversification, Poverty, 
Economic Mobility, and Income Inequality: A Case Study in Village India. Agricultural Economics, 44(4-5), 461-473.

Hosmer, D. W., \& Lemeshow, S. (2000). Applied logistic regression. New York: Wiley.

ILO. (1991). Measurement of the Informal Economy. Geneva: International Labor Office.

Imai, K. S., Raghav, G., \& Ganesh, T. (2015). Does Non-Farm Sector Employment Reduce Rural Poverty and Vulnerability? Journal of Asian Economics, 36, 47-61.

Kowo, S. A., Adenuga, O. A., \& Sabitu, O. O. (2019). The Role of SMEs Development on Poverty Alleviation in Nigeria. Insights into Regional Development, 1(3), 214-226.

Krejcie, R. V., \& Morgan, D. W. (1970). Determining Sample Size for Research Activities. Educational \& Psychological Measurement, 30, 607-610.

Levy, B. (1993). Obstacles to Developing Indigenous Small and Medium Enterprises: An Empirical Assessment (English). The World Bank economic review, 7(1), 65-84.

Lewis, A. (1955). The Theory of Economic Growth. Homewood: Richard D. Irwin.

Liedholm, C., \& Mead, D. C. (1987). Small Scale Industries in Developing Countries: Empirical Evidence and Policy Implications. Michigan : East Lansing.

Little, I. M., Mazumdar, D. P., \& John, M. J. (1987). Small Manufacturing Enterprises: A Comparative Analysis of India and Other Economies (English). New York: Oxford University Press .

Maddala, G. S. (2001). Introduction to Econometrics (3rd ed.). New York: Wiley.

Ministry of Industry and Commerce. (2016). National Policy Framework for Small \& Medium Enterprise (SME) Development Action Plan. Colombo: Ministry of Industry and Commerce.

Mohammed, G. (2016). The Challenge and Prospects of Small Scale Enterprise in Ethiopia: A Survey of Some Selected Small Scale Enterprise in Addis Ababa
City. International Journal of Scientific and Research Publications, 6(5), 617-626.

Musara, M., \& Gwaindepi, C. (2014). Factors within the Business Regulatory Environment Affecting Entrepreneurial Activity in South Africa. Mediterranean Journal of Social Sciences, 5(6), 109-116.

Muturi, M. P. (2015). The Role of Micro and Small Enterprises in Achieving Kenya Vision 2030. International Journal of Economics, 3(5), 1337-1352.

OECD. (2009). The Impact of the Global Crisis on SME and Entrepreneurship Financing and Policy Responses. Paris: Centre for Entrepreneurship OECD.

OECD. (2017). Enhancing the Contributions of SMEs in a Global and Digitalised Economy. Paris: OECD.

Olawale, F., \& Garwe, D. (2010). Obstacles toThe Growth of New SMEs in South Africa: A Principal Component Analysis Approach. African Journal of Business Management, 4(5), 729-738.

Peterise. (2003). Formal and Informal Strategizing in a SME . In M. Daniela, \& G. Lars (Ed.), Proceedings of the International Symposium on Innovation Methods and Innovation Management (pp. 325-336). Chemnitz: Chemnitz University .

Reardon, T., Stamoulis, K., Lanjouw, P., \& Balisacan, A. (2000). Effects of Non-Farm Employment on Rural Income Inequality in Developing Countries: An Investment Perspective. Journal of Agricultural Economics, 51(2), 266-288.

Roy, M., \& Wheeler, D. (2006). A Survey of Microenterprises in Urban West Africa: Drivers Shaping the Sector. Development in Practice, 16(5), 452-464.

Selltiz Selltizet, C. (1976). Research Methods in Social Relations. New York: Holt, Rinehart and Winston.

Shaw, J. (2004). Microenterprise Occupation and Poverty Reduction in Microfinance Programs: Evidence from Sri Lanka. World Development, 32(7), 1247-1264.

Snodgrass, D. R., \& Biggs, T. (1996). Industrialization and the Small Firm: 


\section{Original Article}

Patterns and Policies. Cambridge: Harvard Institute for International Development. Sumanasena, K. (2005). Country Paper-Sri Lanka. Colombo: Sri Lanka Chamber of Small Industries.

Sutton, J. (1997). Gibrat's Legacy. Journal of Economic Literature, 35(1), 40-59.

Thapa, G., Gaiha, R., Kaur, S., Kaicker, N., \& Vashishtha, P. (2013). AgriculturePathways to Prosperity in Asia and The Pacific. Rome: IFAD.

Train, K. E. (2009). Discrete Choice Models with Simulation (2nd ed.). New York: Cambridge University Press.

Tunde, S. H. (2016). Analysis of Relationship Between SME's Employment Growth and Firm Specific Characteristics. Arabian Journal of Business and Management Review, 5(8), 30-39.

Umogbai, M., Diaka, H., \& Ekeh, L. (2016). Small Scale Industries and Poverty Reduction in Benue State, Nigeria. Department of Business Management, 2(8), 1347-1355.

Urban, B., \& Naidoo, R. (2012). Business Sustainability: Empirical Evidence on Operational Skills in SMEs in South Africa. Journal of Small Business and Enterprise Development, 19(1), 146-163.

Vijayakumar, S. (2013). The Status of Small and Medium Enterprises and Promotions for their Growth in Sri Lanka. International Journal on Global Business Management and Research, 6(2), 1-13.

World Bank. (2002). SME, World Bank Group Review of Small Business Activities. Washington, DC: World Bank.

World Bank. (2004). SME, World Bank Group Review of Small Business Activities. Washington, DC: World Bank. 